\title{
Contribution of Dhamtari in Various Movements for Complete Independence (A Study From 1930 To 1947)
}

\author{
VipinTirkey \\ Assistant Professor, History, Guru GhasidasVishwavidyalaya, Bilaspur, C.G.
}

\begin{abstract}
Gandhiji was arrested on $5^{\text {th }}$ May 1930. The agitators included no tax campaign in the programme. The movement had a great impact especially in the Dhamtaritahsil of Raipur district.As soon as on $5^{\text {th }}$ April 1930, Gandhiji inaugurated salt Satyagraha, it affected especially in the Dhamtaritahsil. Regarding the making of salt with soil especially in the tahsil, in a huge crowd Pt. Narayan Rao Medhawale made salt and thus, here too broke the salt law. He made salt through the ancient method out of soil.After the refusal of August Offer 1940, Congress decided to start the "Individual Satyagraha", under the Leadership of Gandhiji. His main motive of the Satyagraha was to protest the policies of British Govt.
\end{abstract}

\section{Introduction}

Dhamtari - Civil Disobedince Movement And Celebration Of First Independence Day And Making Of Salt With Soil 1930

In 1929, a demand for full Swaraj came during Lahore session under the Chairmanship of J. L. Nehru. The British Govt. had rejected the Nehru report of 1928, thus, in Lahore session Congress passed the resolution of complete Independence. On $31^{\text {st }}$ August 1930 the Congress unfurled the National Flag and Congress Committee was authorized to begin the Civil Disobedience Movement in the country. It was also decided that every year on $26^{\text {th }}$ January, the Independence Day should be observed and the First Independence Day was observed on $31^{\text {st }}$ August 1930. In connection of the movement it was declared that to celebrate First Independence Day in various parts of Chhattisgarh. Dr. ShobharamDewangan said that on $26^{\text {th }}$ Jan. 1930, First Independence Day was celebrated in Dhamtaritahsil. It was celebrated as the feast of Diwali. At the Dhamtarichawk Flag hostage was done by Narayan Rao Medhawale, the chawk was in front of the house of BabuChotalal Srivastava; as well patriotic speech was delivered.

After Lahore congress Gandhi put before the Govt., a no. of demands warning it that non-acceptance of these would force him to launch a movement. As Govt. didn't respond to his overtures he started the Civil Disobedience Movement with the programme of no tax to the British Govt., prohibition, no salt tax and protest against military expenditure. On $12^{\text {th }}$ March 1930, Gandhiji proceeded towards the Sea in Gujarat along with his 79 colleagues to Dandi to break the salt laws. It was 200 miles away from Sabarmati Ashram and on foot; it took 24 days to reach Dandi. In this journey Sardar Patel accompanied Gandhiji. On $5^{\text {th }}$ April 1930, he reached there and after the Morning Prayer on $6^{\text {th }}$ April 1930, he started making salt on the Sea shore. He thus broke the salt laws. Gandhiji finalized the programmes of Civil Disobedience Movement as under -

- Indians should break salthon.

- Foreign cloths should not be used.

- Liquor shops should be picketed closed.

- Govt. servants should leave their work.

- Students should boycott the govt. schools and colleges.

Gandhiji was arrested on $5^{\text {th }}$ May 1930 . The agitators included no tax campaign in the programme. The movement had a great impact especially in the Dhamtaritahsil of Raipur district. It was a nationwide movement and even women actively participated in it. As soon as the fire of the movement spread in other parts of the nation, thus it affected in most of the famous places of Chhattisgarh. In Raipur the movement was led by Pt. Ravishankar Shukla, in Mahasamund by Shri Shankar Rao Ganodwale, in Bilaspur by DiwakarKarlikar, in Mungeli by Shri Ramgopal Tiwari, Shri Gajadhar Sao and Shri Kalicharan etc.; as well in Durg by Balodwale Shri Narsingh Prasad Agrawal and finally, the movement left a tremendous impact in Dhamtaritahsil.

As soon as on $5^{\text {th }}$ April 1930, Gandhiji inaugurated salt Satyagraha, it affected especially in the Dhamtaritahsil. Regarding the making of salt with soil especially in the tahsil, in a huge crowd Pt. Narayan Rao Medhawale made salt and thus, here too broke the salt law. He made salt through the ancient method out of soil. Thus, he made two grams salt and which was bought by Karan C. Tejpal a man from Dhamtaritahsil by 61/rupees. By making salt in Dhamtari Nagar, the movement was led by Shri Ganesh Narayan Rao Medhawale. ${ }^{1}$ In order to provide training to the SwayamSevak Shri Medhawale opened a Satyagraha Ashram, where all the SwayamSevak got free food and accommodation etc. Pt. Sundarlal Sharma was the chief organizer of the 
Ashram. SwayamSevak got the lesson of honesty and moral education. Each SwayamSevak had to do Satyagraha and his main work was to go out in order to spread national consciousness by wearing Gandhi cap, national flag and carrying a bag.

\section{Satyagraha Ashram InDhamtari 1930}

In the month of May 1930, Congress leaders decided to establish "Satyagraha Ashram" in the house of NathujiJagtap in Dhamtari tahsil. ${ }^{2}$ For the better organization, total four committees were made -

A. First committee - fund organization,

B. Second committee - grain organization,

C. Third committee - food organization,

D. Forth committee - ashram organization. ${ }^{3}$

In the Satyagraha Ashram training programme was conducted for oneWeek. Training was given from 2 pm to $5 \mathrm{pm}$ thus, it was compulsory for all the volunteers of the Ashram to wear a Gandhi cap, a piece of saffron color cloth, on which SwayamSevak was written and by giving a national flag they were sent out. However, the Ashram became too much popular.

\section{Second Arrival OfGandhiji To Chhattisgarh 1933}

In 1931, Gandhiji was arrested by the British Govt., and in the same year failure of the Second Round Table Conference was held in London; all these events emphasized once more to restart Civil Disobedience Movement in 1932. Thus, Gandhiji on $1^{\text {st }}$ Jan. 1932 led the Movement. As a result in 1932 in Chhattisgarh, an assembly was held under the President ship of Pt. Ravishankar Shukla. He told to people that not to pay taxes, afterwards he was arrested. Once again under the Leadership of Gandhiji, second phase of Civil Disobedience Movement was started from 1932 onwards. This time also in the freedom movement of India, all the famous places of Chhattisgarh contributed and played as important role. Thus, especially the people of Raipur and other places again raised their voices against the British Govt. During this moment Thakur Pyarelal Singh, Shri Laxmi Narayan Das, KhubchandBaghel and Shri NankumarDani etc. were arrested and on the other hand for the better organization of the movement in Chhattisgarh; Shri Ravi Shankar Shukla was appointed as dictator. Beside there were some other leaders like Shri BaliramDubey, Shri YatiyatanLal organized Vanar-Sena in Raipur and other famous leaders also contributed directly or indirectly to make the movement successful.

During the second phase of the Civil Disobedience Movement only in 1933 Gandhiji arrived second time to Chhattisgarh. His main motive of the journey was regarding the welfare of Harizan. ${ }^{4}$ Thus, in connection to this Gandhiji visited the places like Dhamtari, Durg and Bilaspur etc. ${ }^{5}$ As soon Gandhiji arrived in Raipur, he was welcomed at Amanaka School. There Gandhiji was given around 7400/- by Satyagrahis. Then, he went to visit Satnami - Ashram and Anathalaya. For the welfare of Harizan in Chhattisgarh, from 1917 onwards work was done under the guidance of Pt. Sunderlal Sharma. As soon Gandhiji knew about it, he was extremely happy and thus, Gandhiji said to Sharmaji as his Guru. ${ }^{6}$

But on $8^{\text {th }}$ April 1934, second phase of Civil Disobedience Movement was called off by Gandhiji. In 1934 only, there was Central Legislative Assembly took place and in this election Congress got success with a high vote. Shri Ghansyam Singh Gupt was elected its member from Durg. In the Chhattisgarh, Mahakausal Magazine contributed a lot for the national awakening.

\section{Individual Satyagraha InDhamtari 1940}

After the refusal of August Offer 1940, Congress decided to start the "Individual Satyagraha", under the Leadership of Gandhiji. His main motive of the Satyagraha was to protest the policies of British Govt. Thus, Individual Satyagraha was inaugurated by Gandhiji on 17 Oct. 1940, as well Gandhiji nominated first Satyagrahi to VinobhaBhave and second Satyagrahi to Pt. J. L. Nehru. From Raipur district also around 473 people were appointed as Satyagrahis by Gandhiji. In order to make successful to the Satyagraha in Raipur district around 1616 assemblies were organized.

Dhamtaritahsil also contributed a lot in the Individual Satyagraha. From this tahsil many Satyagarhis were arrested, some of them as Hirji Bhai Hansraj Shah, Seth Ramlal Agrawal (Ramiya Seth), Gopal Rao Pawar, Ram BharosaSoni etc. ${ }^{7}$

\section{Quit India Movement 1942}

With the failure of Cripps Mission (1942), the hope of amicable solution of constitutional problem was lost. At the same time there was the danger if Japan's attack on Indian Territory. After this the only course left was that of agitation movement. Forced by circumstances, the Executive of Congress passed "Quit India" on $14^{\text {th }}$ July 1942 a resolution at Wardha. In this proposal it was said that if the English didn't withdraw their control on India, the Indians would be ready to revolt against the alien aggressor. On $8^{\text {th }}$ August 1942 in the Bombay session the Congress Executive accepted it with some modification. Gandhiji said that it would be the 
last struggle of his life. Therefore, he gave the slogan, "Do or Die" to the freedom fighters. The next day in the morning on $9^{\text {th }}$ August 1942, all the prominent leaders were put behind the bars. Yet the movement spread throughout India. The agitators conducted the processions and went on strike. The British Govt. adopted a rigorous policy of suppression. Many times the police had to open fire in which thousands of Indians died. The excited agitators looted the Govt. offices and buildings and burnt the police - stations and post - offices. They dislocated the railway tracks. All this continued till February 1943. It extended up to May 1944, when the Britishers somehow could control it with their better facilities and ammunitions.

In the words of Dr. ShobharamDewangan, that the impact of Quit India Movement was seen among the youngsters of Dhamtaritahsil. Here also processions, assemblies and speech were delivered and many were arrested during the movement, and most of them got and 6 months jail. Surrounding village of the tahsil was also awakening through the movement and many were sent into jail for 6 months. ${ }^{8}$

\section{Freedom At Midnight 1947}

After Lord Wavell, Mountbatten became the Viceroy of India. According to the declaration of Atlee, Mountbatten requested to Pt. J. L. Nehru and Sardar Patel to accept the demand of Pakistan raised by Jinnah and League. Mountbatten went to England to have consultation on partition and when he came back, he publishes his plan on $3^{\text {rd }}$ June 1947. It is known as "Mountbatten Plan". On insistence from Mountbatten, Jinnah accepted the Plan. On $15^{\text {th }}$ June 1947 the Congress too under pressure accepted it. In July this plan was executed by Indian Independence Act, 1947.

On $4^{\text {th }}$ July 1947 , this plan was placed in the House of Common. On $18^{\text {th }}$ July 1947 , the British Parliament passed this bill. According to it, two separate nations were created. Lord Mountbatten went to Karachi on $13^{\text {th }}$ August 1947 and transferred the power to Pakistan. Mr. Jinnah was made the Governor General of the new nation Pakistan. On $14^{\text {th }}$ August 1947, at midnight India too became a free nation. Lord Mountbatten was made the Governor General of India. Lord Mountbatten retired from his post and C. Raja Gopalachari was appointed the new Governor General. On $26^{\text {th }}$ January 1950, the Indian Constitution was enforced and it became the Republic Day of India.

\section{Welcome Of Independence In Chhattisgarh 1947}

In 1947, since Chhattisgarh was a part of Madhya Pradesh, thus on $14-15^{\text {th }}$ at midnight after five minutes of a golden day, first Provincial Governor of free India Mr. M. Pakvasa took the oath in Madhya Pradesh. On $15^{\text {th }}$ Aug. 1947 first Chief Minister of Madhya Pradesh Pt. Ravishankar Shukla hoisted national flag on the Sitabardi fort at capital Nagpur. ${ }^{9}$ At that moment members from Bhonsle family and people of that region were presented there and Pt. Ravisankar Shukla addressed all of them. In Raipur also at midnight of $14^{\text {th }}$ $15^{\text {th }}$ Aug. $1947^{10}$ people of this region welcomed and celebrated with great joy and in all the education institutes flag hoisting took place. During this day Commissioner of Raipur K. B. L. Seth declared to set free around 200 prisoners from jail. On $15^{\text {th }}$ Aug. 1947 in Raipur at 7.35 am R. K. Patil (food minister) hoisted flag in police line. ${ }^{11}$ There he addressed people at the office of municipal and read the massages of Gandhiji, Pt. Nehru and Pt. Ravisankar Shukla. On the next day $16^{\text {th }}$ Aug. he inaugurated statue of S. C. Bose at station. From $14^{\text {th }}$ to $16^{\text {th }}$ Aug. all the wine shops were closed. Here, sweets were distributed to all people and the joy of independence spread throughout Raipur district from city to village. On the other in Durg flag hoisting was done by Shri Ghansyam Singh Gupt at $8.30 \mathrm{am}^{12}$ and addressed to public in an assembly, as well read the messages of Pt. Nahru. He too was at this time the President of Provincial Assembly. He motivated to all people and told to live in unity and peace. On $15^{\text {th }}$ Aug., At 8.00 am flag hoisting took place in Bilaspur too by the Parliament Secretary and Provincial Congress President Pt. Ramgopal Tiwari. In order to welcome the day this city was fully decorated everywhere. On this day Pt. Ramgopal Tiwari addressed in a huge crowd and read the message of Gandhiji and Pt. Nehru. In memorial of the Independence Day a tree was planted at Gandhi Chawk in Bilaspur. On the other hand at various places Jai Stambh was built up. These were the main places where it was constructed, such as Saraipali, Basna, Pendra, Gariaband, Devbhog, Chura, Fageshwar, Nawapara, Arang, Mahasamund, Pithora, Saraipali, Ratanpur, Bhatapara, Baloda Bazaar, Dhamtari, Patan, Kurud, Kanker, Abhanpur, Jagadalpur, Ambikapur, Raigarh, Bemetara, Akaltara, Shivrinarayan, Mungeli, Janjir, Katghora, Kawardha, Baikunthpur, Surajpur, Ramanujgunj, Rajnandgaon etc.; various programmes were conducted for weeks in cities as well in each villages in order to celebrate the Independence Day. But in one place at Kargiroad (Kota), the Assistant Post-Master of Kargiroad refused to hoist national flag. ${ }^{13}$

Any way in most of the places this day was celebrated with great joy and happiness. Many congress leaders and social workers gave the message of peace, love and unity among Hindu - Muslim. People of this region celebrated it with no violence. Though here was some critical situation arose but by the prominent leaders of these areas helped a lot to maintain peace.

At the end it would be said that the various movements from 1930 to 1947 till the Independence of India, all these left a great impact upon people of Dhamtaritahsil. Thus, all the movements developed national 
consciousness among people of Dhamtari areas. Therefore, all people actively participated in all these movements and made successful in order to achieve complete swaraj. Though the various leaders of Raipur district sacrificed a lot to attain Swaraj, on the other hand many people of these regions raised their voices against the British government and also fought for their rights. All the above written great events helped people to gather under one flag, thus after a long struggle, people of these regions as well nation got complete freedom from the British Crown in 1947.

\section{References:}

[1]. Dr. Bhagwan Singh Verma, Chhattisgarh KaItihas (Prarambh Se 2000 AD), P.229.

[2]. Dr. Ramgopal Sharma, Dr. Taru Tiwari, Chhattisgarh KaPrashasanEvamSwatantraSangramAndolan (1854-1947), P.41.

[3]. Ibid., P.42

[4]. Dr. Arvind Sharma, Chhattisgarh KaRajnitikItihas, P.196.

[5]. Dr. Bhagwan Singh Verma, Chhattisgarh KaItihas (Prarambh Se 2000 AD), P.233.

[6]. Ibid., P.233.

[7]. Dr. Ramgopal Sharma, Dr. Taru Tiwari, Chhattisgarh KaPrashasanEvamSwatantraSangramAndolan (1854-1947), P.51

[8]. Dr. Ramgopal Sharma, Dr. Taru Tiwari, Chhattisgarh KaPrashasanEvamSwatantraSangramAndolan (1854-1947), P.56.

[9]. Dr. Arvind Sharma, Chhattisgarh KaRajnitikItihas, P. 286.

[10]. Ibid., p. 287

[11]. Ibid., p. 287

[12]. Ibid., p. 287

[13]. Dr. Arvind Sharma, Chhattisgarh KaRajnitikItihas, P. 288. 